\title{
A Case of Sclerosing Pneumocytoma: A Rare Lung Tumor
}

\author{
Nadir Bir Akciğer Tümörü olan Sklerozan Pnömositoma Olgusu
}

Abdulkadir Yasir Bahar', Sercan Şimsek², Harun Çıralık'

\section{Abstract}

Sclerosing pneumocytoma is a rare, benign neoplasm which may be in solid, papillary, sclerosing or hemorrhagic patterns histologically, and its papillary surfaces are covered with hyperplastic type 2 pneumocytes. It is often seen in middle-aged adults and women with no recurrence and no reported diseaserelated deaths. Herein, we present a 50-year-old female case of sclerosing pneumocytoma case who was diagnosed incidentally during acute bronchitis episode.

Key words: Sclerosing pneumocytoma, TTF-1, EMA.

\section{Özet}

Sklerozan pnömositoma histolojik olarak solid, papiller, sklerotik, hemoraiik paternlerde olabilen, papiller yüzeyleri hiperplastik tip 2 pnömositlerle döşeli çoğunlukla orta yaş erişkin ve kadınlarda görülen benign, rekürrens ya da hastalığa bağlı ölüm bildirilmeyen, nadir görülen bir neoplazidir. Biz 50 yaşındaki kadın hastada akut bronşit atağı sırasında insidental olarak saptanan sklerozan pnömositoma olgusunu sunduk.

Anahtar Sözcükler: Sklerozan Pnömositoma, TTF-1, EMA.
This tumor previously defined as a vascular tumor and named as a sclerosing hemangioma due to its significant angiomatoid properties, which derived from the primitive respiratory epithelium in the ultrastructural and immunohistochemical studies $(1,2)$. It is common in the mid-aged adults (range, 11 to 80 years, median $=46$ ) $(3,4)$. About $80 \%$ of the cases are women (5). It frequently shows solitary or peripheral localization and is more than one in $4 \%$ of the cases (6). It is mostly asymptomatic (80\%). However, cough, chest pain, or hemoptysis may present (2).

\footnotetext{
'Department of Pathology, Sütçü İmam University Faculty of Medicine, Kahramanmaraş, Turkey

${ }^{2}$ Department of Pathology, Firat University Faculty of Medicine, Elazı̆̆, Turkey

'Sütçü İmam Üniversitesi Tıp Fakültesi, Patoloji Anabilim Dalı, Kahramanmaraş

${ }^{2}$ Fırat Üniversitesi Tıp Fakültesi, Patoloji Anabilim Dalı, Elazığ
}

Submitted (Başvuru tarihi): 28.1 1.2015 Accepted (Kabul tarihi): 1 1.01.2016

Correspondence (iletişim): Abdulkadir Yasir Bahar, Department of Pathology, Sütçü İmam University Faculty of Medicine, Kahramanmaraş, Turkey

e-mail: ayasirbahar@gmail.com 


\section{CASE}

A 50-year-old woman was admitted to our emergency unit with fever, cough, and expectoration complaints and was incidentally diagnosed with a tumor during acute bronchitis episode. Her medical history revealed no smoking habit. A detailed examination was performed with a preliminary diagnosis of acute bronchitis. A lesion was detected in her direct pulmonary radiography and pulmonary computed tomography (CT) was obtained following treatment for an infection. The CT images revealed an $11 \times 9.5 \mathrm{~mm}$ nodular lesion of the soft tissue density in the fissure which was adjacent to the inferior lobe anterobasal segment of the right lung (Figure 1A). The mass was removed through wedge resection. The macroscopic evaluation showed $1 \mathrm{~cm}$ round lesion, which had a harder structure, no capsule, contained brown-black hemorrhagic foci, and separated from the surrounding pulmonary tissues through regular borders (Figure 1B).

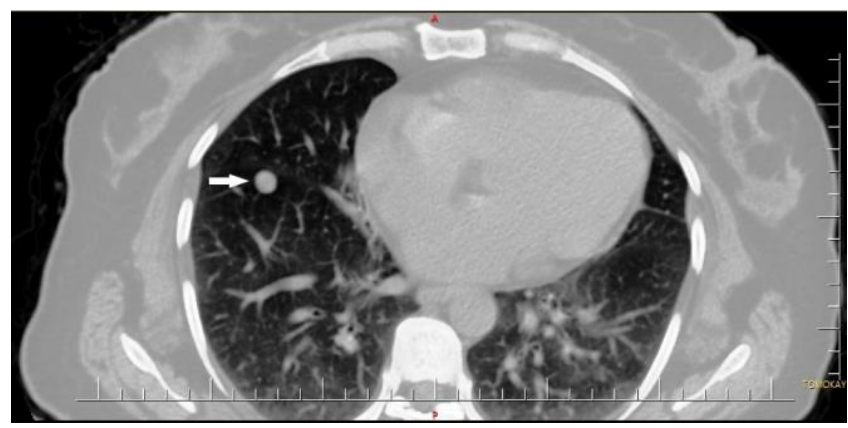

Figure 1a: An $17 \times 9.5 \mathrm{~mm}$ nodular lesion in the fissure, adjacent to the inferior lobe anterobasal segment of the right lung in thoracic CT axial images

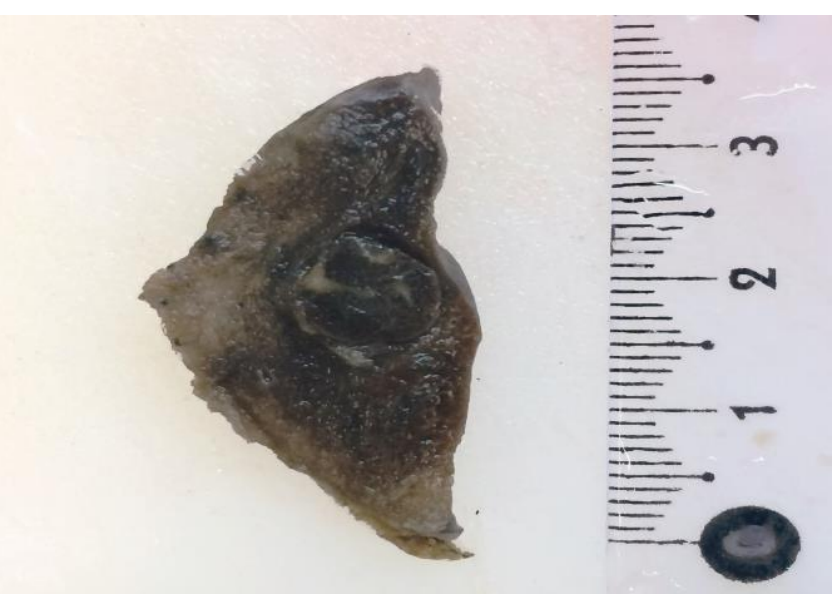

Figure 1b: Gross specimen obtained following the wedge resection showing an ill-demarcated, non-capsulated, round-shaped, solid mass with containing foci of hemorrhage
The microscopic evaluation of the tumor with hematoxylin and eosin staining included cystic and solid stromal structures. The cystic fields were covered with flat epithelial cells including erythrocytes. Papillary projections were present in some of the cysts. Stromal cells were roundshaped, had spindle-shaped elongated nuclei, and wide eosinophilic cytoplasm with no atypia. Stroma had a rich vascular structure and included hyalinized sclerotic areas and scattered chronic inflammatory cells (Figure 2A-C).
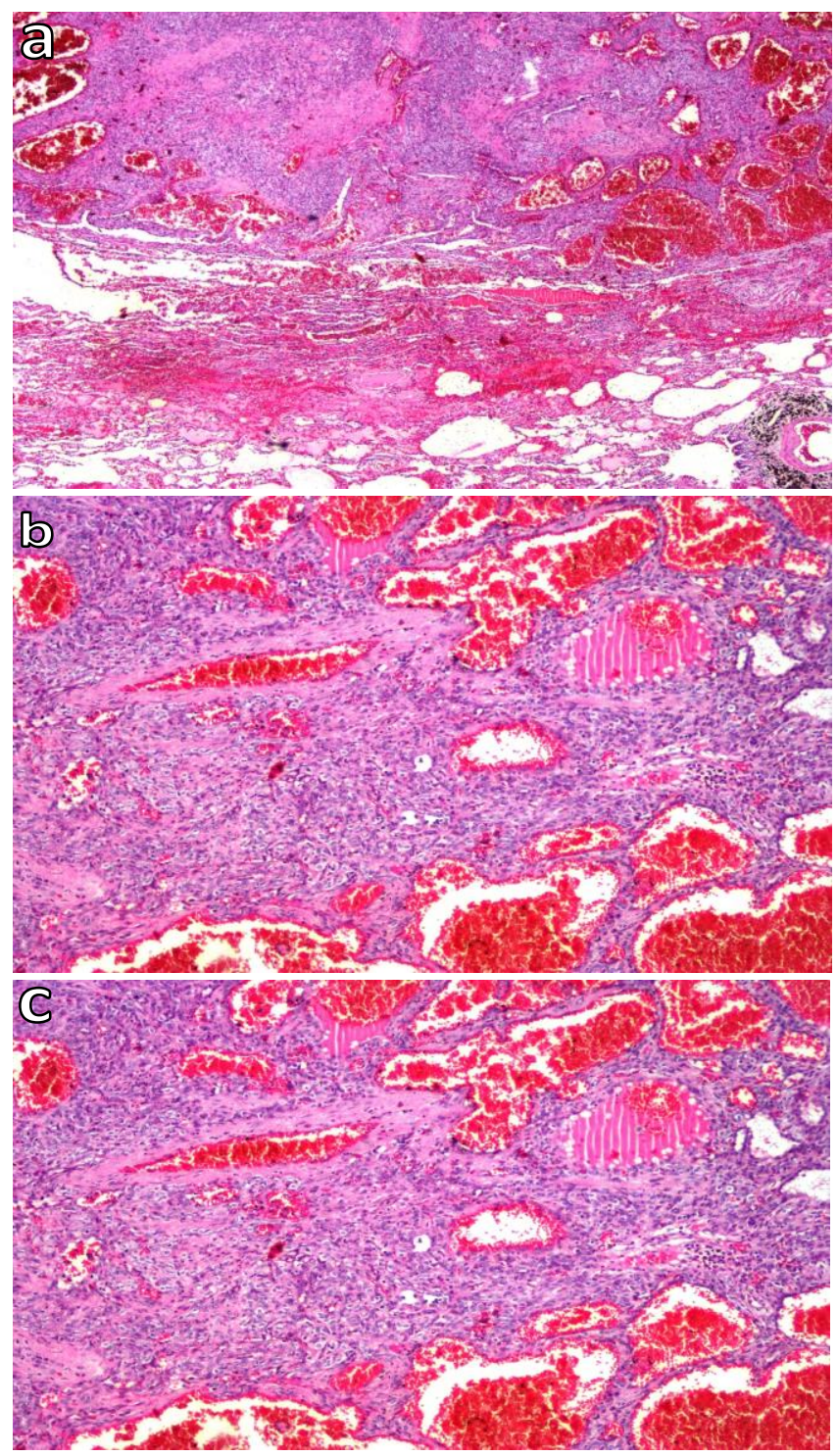

Figure 2a, b and c: Microscopic examination showing hemorrhagic (left) and solid (right) areas of tumor above the normal pulmonary tissue (A) (H\&E, 40x). Solid areas contain round stromal cells some with a clear cytoplasm (B) (H\&E, 100x). Hemorrhagic areas contain irregular spaces lined by flattened cells, filled with red blood cells (C) (H\&Eosin, 400x) 
According to the immunohistochemical staining, flat epithelial cells lining the cyst and stromal cells were TTF-1 $(+)$, vimentin $(+)$, EMA $(+)$, chromogranin A (-), S-100 (), desmin (-), actin (-) and CD34(-). CD34 was (+) in only vascular structures. Flat epithelial cells lining the cyst were pancytokeratin (+), where stromal cells were (-). Ki-67 proliferation index was evaluated to be $1-2 \%$ (Figure 3A$5 B)$.

Based on these findings, the patient was diagnosed with sclerosing pneumocytoma. The patient was discharged without any complication two weeks later.

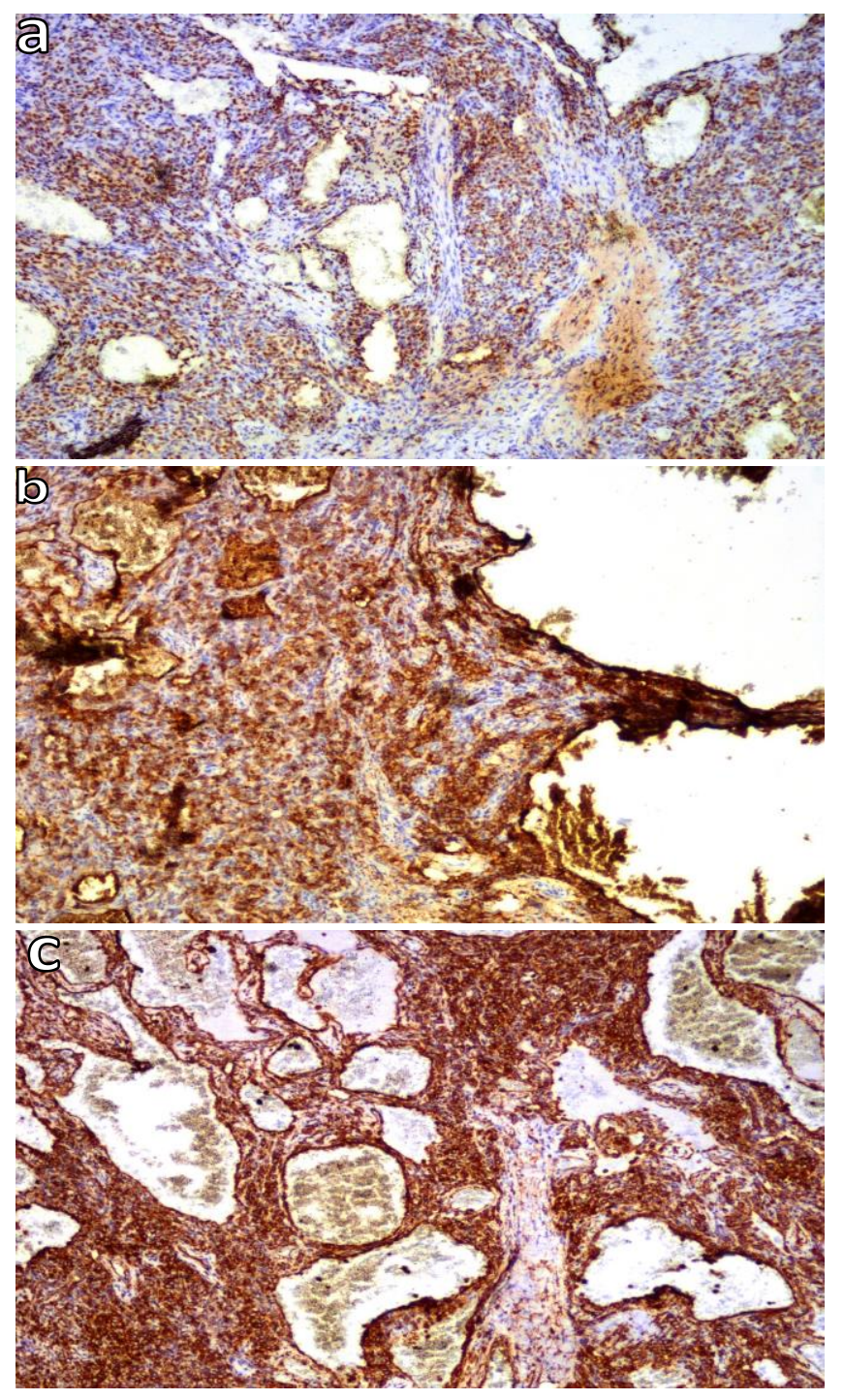

Figure $3 a, b$ and $c:$ Immunohistochemical staining showing that the both stromal and cyst lining epithelial cells are positive for TTF-1 (A), EMA (B), and vimentin (C) [original magnification 100× ]
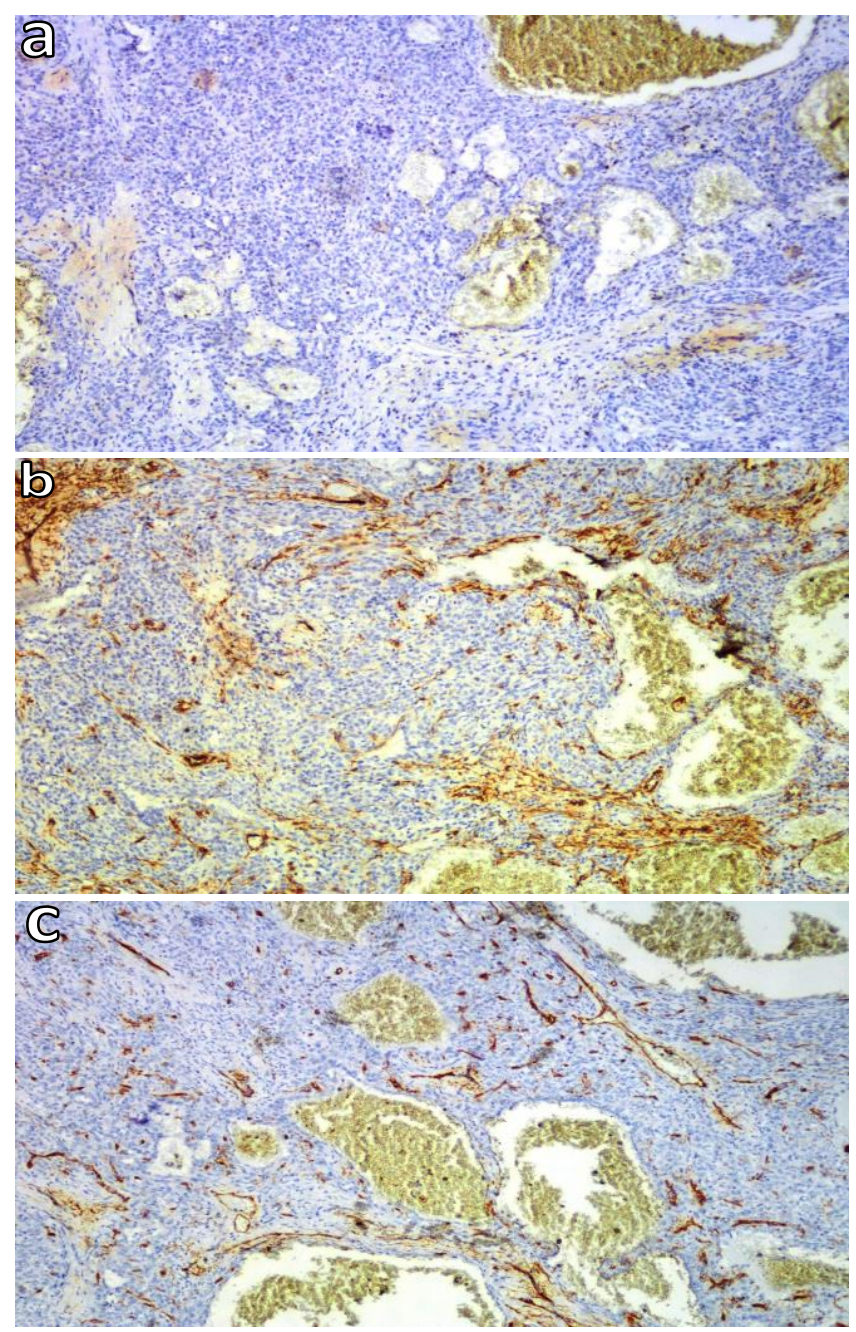

Figure 4a, $b$ and $c$ : Negative for Chromogranin-A (A), SMA (B) and CD34 (C) [original magnification $100 \times$ ]

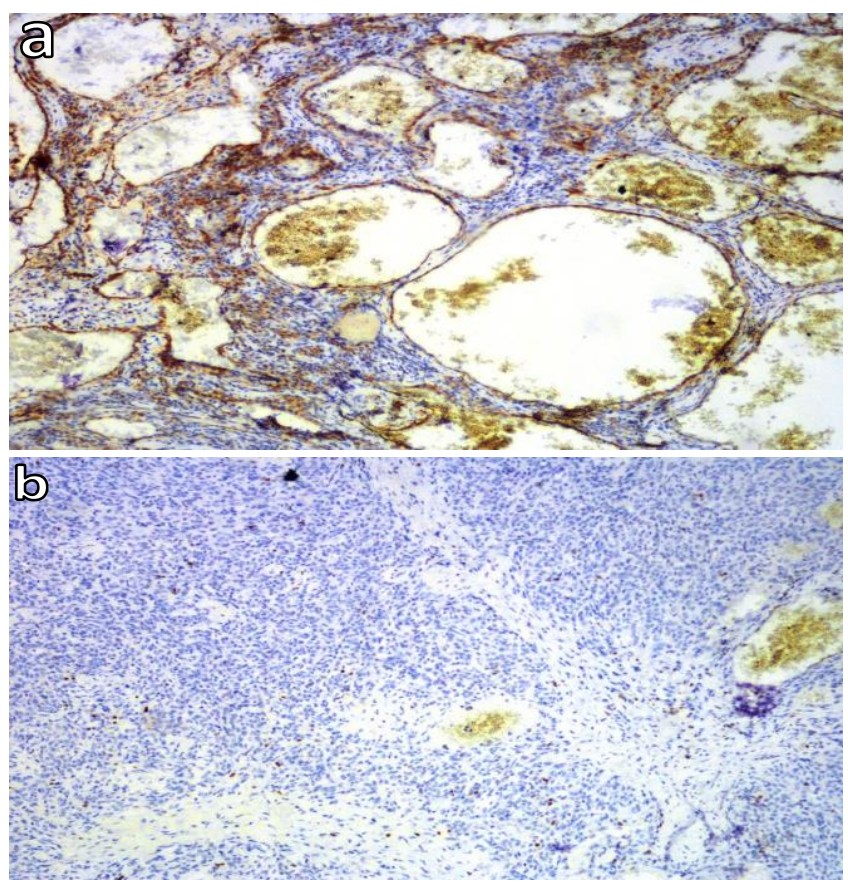

Figure 5a and b: Pancytokeratin positivity in only the cyst lining epithelial cells (A). Intratumoral inflammatory cells, but not tumor cells, are positive for KI67 (B) [original magnification 100×] 


\section{DISCUSSION}

Sclerosing pneumocytoma is a benign pulmonary tumor observed rarely in Western countries and more frequently in the Eastern Asia (7). Radiologically, the tumor is wellbordered, frequently cystic, rarely calcified in plain radiographs, significantly contrasted and well-bordered in CT (8). Its hemorrhagic component helps to discriminate it from other lesions in magnetic resonance imaging (MRI) (9).

They are macroscopically $0.3-8 \mathrm{~cm}$ in-size, well-bordered solid masses with no capsule and lobar distribution, and they contain grey-yellow hemorrhagic foci. Cystic or calcific changes can be also observed (10).

Microscopically, they are formed by two different types of cells which are round stromal cells and surface cells (11). Round stromal cells have central localized nuclei without significant nucleoli. Their mitotic index is low (1/10 BBA). Surface epithelial cells has the morphologic properties of type 2 pneumocytes, they are clear, vacuolated, multinucleated, cuboidal flat epithelial cells. In the majority of the patients, different combinations of the papillary, solid, sclerotic, and hemorrhagic patterns are observed. In general, one of these patterns is dominant. Hemorrhagic pattern includes wide spaces filled with blood, covered by flat epithelial cells and a stromal component. Papillary pattern includes round cells in the papillary stalk and complex papilla lined through a cuboidal surface epithelium demonstrating sclerosing and sometimes myxoid changes. In the sclerotic pattern, co-existence of dense hyalinization and papillary and solid structures is present around the hemorrhagic areas. Solid pattern includes cuboidal surface epithelium which formed small tubules between the round stromal cell clusters $(11,12)$. In our case, hemorrhagic and solid pattern areas were significant. There were also hyalinized sclerotic areas, although less significant.

Immunohistochemically, round stromal cells were TTF-1 and EMA (+), and pancytokeratin (-). The surface epithelium was TTF-1, EMA, and pancytokeratin (+), and CEA, S100, smooth muscle actin, chromogranin-a, and CD34 negative $(2,7,13)$.

Vascular tumors, carcinoid tumor, and pulmonary hamartoma were considered in the discriminative diagnosis. Pulmonary hamartoma are the mixture of different tissues such as cartilage, muscular and fat tissues, and myxoid stroma. A glomus tumor was initially suspected, since the flat cells lining the cystic spaces filled with blood resembled endothelial cells and stromal round cells were present in our case. However, CD34 and SMA negativity and TTF-1 and EMA positivity in both two components are in the favor of sclerosing pneumocytoma. Chromogranin A negativity excluded the possibility of a carcinoid tumor.

In the prognosis, it is a benign tumor with no reported disease-related death and shows no recurrence. Lymph node involvement has been reported in $1 \%$ of the cases. Surgical excision is usually sufficient for the treatment. Lymph node dissection may be necessary in case of metastasis suspicion (14).

\section{CONFLICTS OF INTEREST}

None declared.

\section{AUTHOR CONTRIBUTIONS}

Concept - A.Y.B., S.Ş., H.Ç.; Planning and Design A.Y.B., S.Ş., H.Ç.; Supervision - A.Y.B., S.Ş., H.Ç.; Funding -; Materials - A.Y.B., H.Ç.; Data Collection and/or Processing - A.Y.B., S.Ş.; Analysis and/or Interpretation A.Y.B., H.Ç.; Literature Review - A.Y.B., S.S..; Writing A.Y.B., S.Ş., H.Ç.; Critical Review - A.Y.B., H.Ç.

\section{YAZAR KATKILARI}

Fikir - A.Y.B., S.Ş., H.Ç.; Tasarım ve Dizayn - A.Y.B., S.Ş., H.Ç.; Denetleme - A.Y.B., S.Ş., H.Ç.; Kaynaklar -; Malzemeler - A.Y.B., H.Ç.; Veri Toplama ve/veya İşleme A.Y.B., S.Ş.; Analiz ve/veya Yorum - A.Y.B., H.Ç.; Literatür Taraması - A.Y.B., S.Ş.; Yazıyı Yazan - A.Y.B., S.Ş., H.Ç.; Eleştirel İnceleme - A.Y.B., H.Ç.

\section{REFERENCES}

1. Chan AC, Chan JK. Pulmonary sclerosing hemangioma consistently expresses thyroid transcription factor-1 (TTF1): a new clue to its histogenesis. Am J SurgPathol 2000; 24:1531-6. [CrossRef]

2. lyoda A, Hiroshima K, Shiba M, Haga Y, Moriya Y, Sekine $Y$, et al. Clinicopathological analysis of pulmonary sclerosing hemangioma. Ann Thorac Surg 2004; 78:1928-31. [CrossRef]

3. $\mathrm{Ng} \mathrm{WL}, \mathrm{Ma} \mathrm{L}$. Is sclerosing hemangioma of lung an alveolar mixed tumour? Pathology 1983; 15:205-11. [CrossRef]

4. Spencer $\mathrm{H}$, Nambu S. Sclerosing haemangiomas of the lung. Histopathology 1986; 10:477-87. [CrossRef]

5. Devouassoux-Shisheboran M, Hayashi T, Linnoila RI, Koss MN, Travis WD. A clinicopathologic study of 100 cases of pulmonary sclerosing hemangioma with immunohistochemical studies: TTF-1 is expressed in both round and surface cells, suggesting an origin from primi- 
tive respiratory epithelium. Am J Surg Pathol 2000; 24:906-16. [CrossRef]

6. Lee ST, Lee YC, Hsu CY, Lin CC. Bilateral multiple sclerosing hemangiomas of the lung. Chest 1992; 101: 572-3. [CrossRef]

7. Flieder DB. Benign neoplasm of the lungs. In Goldblum JR, Zander DS, Farver CF, eds. Pulmonary pathology: a volume in the series foundation in diagnostic pathology. 1 st ed. Churchill Livingstone: Elsevier, 2008:683-6.

8. Im JG, Kim WH, Han MC, Han YM, Chung JW, Ahn JM, et al. Sclerosing hemangiomas of the lung and interlobar fissures: CT findings. J Comput Assist Tomogr 1994; 18:34-8. [CrossRef]

9. Fujiyoshi $F$, Ichinari $N$, Fukukura $Y$, Sasaki $M$, Hiraki $Y$, Nakajo M. Sclerosing hemangioma of the lung: MR findings and correlation with pathological features. J Comput Assist Tomogr 1998; 22: 1006-8. [CrossRef]

10. Nicholson AG, Magkou C, Snead D, Vohra HA, Sheppard MN, Goldstraw P, et al. Unusual sclerosing hae- mangiomas and sclerosing haemangioma-like lesions, and the value of TTF- 1 in making the diagnosis. Histopathology 2002; 41:404-13. [CrossRef]

11. Katzenstein AL, Gmelich JT, Carrington CB. Sclerosing hemangioma of the lung: a clinicopathologic study of 51 cases. Am J Surg Pathol 1980; 4:343-56. [CrossRef]

12. Dağlar E, Kulaçoğlu S, Ergül G. Sklerozan hemanjioma (Sklerozan pnömositoma) Olgu sunumu. Tur Toraks Der $2011 ; 12: 161-4$. [CrossRef]

13. Ekinci $G H$, Hacıömeroğlu $O$, Ersev A, Alpay L, Şen A, Güney PA, et al. Pulmonary sclerosing hemangioma (Pneumocytoma): an analysis of 8 cases. Eurasian J Pulmonol 2015; 17:159-62. [CrossRef]

14. Yano M, Yamakawa Y, Kiriyama M, Hara M, Murase T. Sclerosing hemangioma with metastases to multiple nodal stations. Ann Thorac Surg 2002; 73:981-3. [CrossRef] 